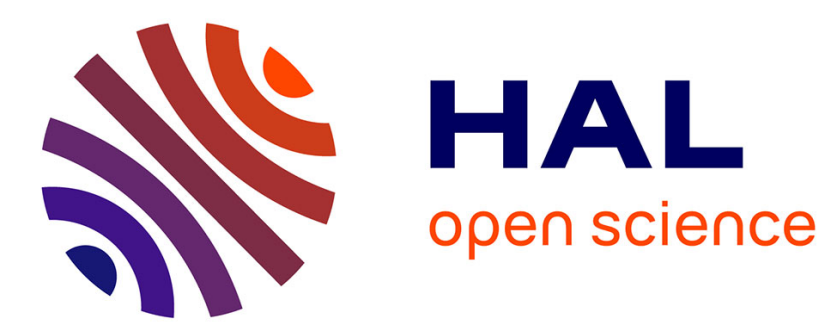

\title{
Corporate Social Responsibility Boosts Value Creation at the Base of the Pyramid
}

Thomas André

\section{To cite this version:}

Thomas André. Corporate Social Responsibility Boosts Value Creation at the Base of the Pyramid. 2014. hal-00989791

\author{
HAL Id: hal-00989791 \\ https://hal.science/hal-00989791 \\ Preprint submitted on 12 May 2014
}

HAL is a multi-disciplinary open access archive for the deposit and dissemination of scientific research documents, whether they are published or not. The documents may come from teaching and research institutions in France or abroad, or from public or private research centers.
L'archive ouverte pluridisciplinaire HAL, est destinée au dépôt et à la diffusion de documents scientifiques de niveau recherche, publiés ou non, émanant des établissements d'enseignement et de recherche français ou étrangers, des laboratoires publics ou privés. 


\section{ECOLE POLYTECHNIQUE}

CENTRE NATIONAL DE LA RECHERCHE SCIENTIFIQUE

CORPORATE SOCIAL RESPONSIBILITY BOOSTS VALUE CREATION AT THE BASE OF THE PYRAMID

Thomas ANDRE

Cahier $n^{\circ}$ 2014-11

\section{DEPARTEMENT D'ECONOMIE}

Route de Saclay

91128 PALAISEAU CEDEX

(33) 169333033

http://www.economie.polytechnique.edu/

mailto:chantal.poujouly@polytechnique.edu 


\title{
Corporate Social Responsibility Boosts Value Creation at the Base of the Pyramid
}

Thomas André

Ecole Polytechnique, Route de Saclay, 91128 Palaiseau, France

thomas.andre@polytechnique.edu

\begin{abstract}
Multinational enterprises (MNEs) have embraced the possibility to find growth or strategic opportunities by targeting the Base of the Pyramid (BoP) segment, while contributing to alleviate poverty. Taking stock of the notorious early BoP initiatives shows that the bet made upon this responsible commitment is not yet won. Indeed, some were relegated to philanthropic programmes or simply dismantled, highlighting a tension to combine both societal and financial sustainability. The paper questions why and how MNEs reposition the value creation of their current BoP initiatives in regards of their Corporate Social Responsibility (CSR) strategy. We provide an empirical analysis of present BoP initiatives, based on an embedded multiple-case study of seven MNEs' initiatives and seventeen of their field projects. The paper highlights three levels of CSR engagement at the firm level, which will translate into different strategies, organisations and types of value creation for BoP initiatives. We deliver novel insights for the study of the "business cases" of BoP strategies, which aim at gaining legitimacy, incubating strategic change and reaching profitable growth.
\end{abstract}

Keywords: Multinational Enterprises, Corporate Social Responsibility (CSR), Base of the Pyramid (BoP), business case

\section{Introduction}

Multinational enterprises (MNEs) have embraced the possibility to find growth or strategic opportunities by targeting poor population markets while contributing to alleviate poverty of the so called "Base" or "Bottom of the Pyramid" (BoP) (Prahalad \& Hammond, 2002; Prahalad \& Hart, 1999). In 2000, Hewlett-Packard (HP) was one of the first MNEs to launch a global and promising initiative, called e-Inclusion, aimed at tackling the digital divide. The program, supported by Carly Fiorina, the former CEO of HP, extended the company's traditional philanthropic engagement to become the new strategic commitment of the company (Traça \& Foryt, 2004). E-Inclusion implemented numerous projects by marketing products and services in underserved communities as a prospective growth for HP in emerging countries. Five years later, Carly Fiorina was ousted from the company. Her predecessor terminated the e-Inclusion initiative, considering that it could not demonstrate sufficient returns on investments (McFalls, 2007; Schwittay, 2011). Supports to entrepreneurship or improved education were brought back to philanthropic activities of the company. The case of HP is not the sole example of a "failure" in targeting the base of the pyramid segment. In this regard, Simanis and Milstein, when reviewing such business divestments, urge MNEs to "bring business fundamentals back to the forefront of the BoP concept" (Simanis \& Milstein, 2012). This highlights the tension that MNEs are facing to reconcile both objectives of their BoP strategies, namely being economically sustainable in time and being an integrated part of societal responsibility concerns.

Private sector involvements and academia research have made their way towards the expansion in poor population markets since the first introduction of the concept of "Base" or "Bottom of the Pyramid" (BoP) made by C.K. Prahalad and S. Hart in 1998 (Prahalad \& Hart, 1999). Companies launched initiatives following Prahalad's initial focus on ventures targeting BoP markets which are therefore pursuing profits and social outcomes (Prahalad \& Hammond, 2002; Prahalad \& Hart, 1999) or Muhammad Yunus' concept of social business for which ventures have a specific focus on social outcomes (Yunus, 2008). As depicted by Simanis, first ventures have been highly studied (Simanis \& Milstein, 2012). Initiatives led by Hindustan Lever Ltd in India and its Wheel detergent, $P \& G$ and its Pur water purification sachets, or Hewlett Packard (HP) and its e-Inclusion distribution approach shed light on the potential for MNEs to reach untapped markets by selling to the poor. Critiques emerged from some academics about the fact that no market exists, that the BoP populations should be rather included into the business models or that projects do not actually target the poorest (Crabtree, 2007; Karnani, 2006, 2007b; Warnholz, 2007). However, critiques did not break the emulation between practitioners. A few years later, numerous initiatives were launched with the vision of integrating the poor populations in the design of the ventures, characterizing them as a "BoP 2.0" generation (Simanis \& Hart, 2008). Projects like Grameen Danone Foods Ltd and its enriched yogurts distributed in Bangladesh, Patrimonio Hoy from Cemex providing financing 
and services to build affordable housing extensions, or the Community Cleaning Services initiated by SC Johnson in the slums of Nairobi, Kenya, show the development of ventures led by Corporate Social Responsibility (CSR) concerns. This trend emphasizes the aspiration of a double or even triple bottom line from MNEs. In that sense, companies seems for having adopted Davidson's recommendation, whom urged MNEs to incorporate the core elements of CSR into the BoP concept "if they are to have any chance of success" (Davidson, 2009). In a similar way that it has been studied for environmental concerns and climate change issues (Arjaliès \& Ponssard, 2010), we might wonder if BoP strategies as an integrated part of a CSR strategy, will have more chance to maintain and scale up if CSR is itself deeply integrated into the overall business strategy. In the following, we consider CSR following the European Commission definition (2001) as "a concept whereby companies integrate social and environmental concerns in their business operations and in their interaction with their stakeholders on a voluntary basis". Therefore, we assume that CSR cannot be solely assimilated to a philanthropic approach as it can be described in some of the literature (Carroll, 1991).

The aim of the paper is to question why and how do MNEs implementing BoP initiatives reposition their value creation system in regards of their CSR strategy? Paradoxically, numerous multinationals continue or recently started their own BoP initiative. Their business efforts are often motivated by ethical concerns from their directions, which helped to mobilize collaborators. Meanwhile, managers leading BoP initiatives seem overtaken by business challenges as MNEs' directions are also requiring short-term returns, while they are still in a process of long-term innovation to address social issues (Seelos \& Mair, 2007). We argue that BoP strategies will have any chance to maintain if they articulate in the Corporate Social Responsibility (CSR) policies, which are themselves clearly embedded in companies' strategy. This paper provides empirical elements to the discussion on the BoP concept, using an MNE's perspective, as the central entity addressed by Prahalad's initial work, and which have been identified as lacking in the present BoP literature (Kolk, Rivera-Santos, \& Rufin, 2012).

We construct our empirical analysis on an embedded, multiple-case study for theory building (Eisenhardt \& Graebner, 2007; Yin, 1994) of seven MNEs, which are implementing BoP initiatives: Danone, Electricité de France (EDF), Essilor, Grundfos, Lafarge, Schneider Electric and Veolia Environement. While studied companies are not statistically representative, they were selected based on their role in the domain of BoP strategies (i.e. leadership), their diversity of industry (i.e. cross sector), their geographies of intervention (i.e. cross country) and their modality of operations (i.e. different business models). Ten semi-structured interviews with managers or directors at the corporate level permitted to focus on the strategy and organization of the cases, which completed the integration of internal documents and secondary data (institutional documents, communication documents, previous cases, and press articles). Survey questionnaires addressed to managing directors of seventeen BoP projects at the field level - mostly composed of multiple-choice questions based on the review of the literature - completed the sub-case analysis, and focused on the value creation experienced at the local level.

Our findings clarify the deep rooting of BoP initiative within the sustainable development policies. We reveal that the more CSR engagements are integrated into the firms' strategy, the more BoP strategies will maintain and scale up. We reassert the embeddedness of a double value creation effort for both the society and the company in MNEs strategy, translating into different strategies, organisations and types of value creation for BoP initiatives. We deliver novel insights for an emerging pattern of the "business cases" of BoP initiatives that go well beyond the sole search for direct profit. Indeed, their strategy derives from three different business rationales, namely gaining legitimacy; incubating strategic change; and reaching profitable growth. Implementations of $\mathrm{BoP}$ projects at the local level testify that MNEs, which intends to reshape their value creation, go actually beyond a mere communication from the headquarters level. We present the evidence of a progressive development at the local level of enhanced performance and impact measurement methods that consider both societal and economic outcomes. While more intangible returns for the company are acknowledged by managers but not actually monitored, we strongly encourage future research to explore the management control for sustainability performance of the BoP initiatives. This would guide managers and directors in assessing a business case, in order to build MNEs rationale and demonstrate the broader value creation of BoP projects that encompass financial and societal returns but also intangible business impacts.

The remainder of the paper is organised as follows. In section 2, we derive a theoretical rationale to support our hypotheses of an integrated CSR BoP model, based on the review of successes and failures in the BoP literature. We present our empirical strategy and data in Section 3. Section 4 derives the results of the cross case analysis and section 5 concludes. 


\section{Towards an integrated CSR BoP model? A review of successes and failures}

\subsection{A common anchorage of value creation for BoP and CSR strategies}

Efforts have been done to describe MNEs' motivations for adopting CSR and describe its business case. For instance, Bansal and Roth (2000), in their study of "corporate ecological responsiveness", identified three motivations, namely "competitiveness", "legitimation", and "ecological responsibility", which respectively pursue profitability, firm survival and corporate morale. Speaking about broader economic, social, and environmental concerns of the firms Hart and Milstein (2003) developed a sustainable-value framework linking the challenges of global sustainability with the creation of shareholder value. They name four ways to create value for the company: "innovation and repositioning", "growth and trajectory", "cost and risk reduction", and "reputation and legitimacy". These four categories are meant to capture a double tension, on the one hand, to reach short-term results while experimenting future growth, and on the other hand, to exploit internal capabilities while infusing business perspective from external stakeholders ( $\mathrm{S}$. Hart, 2007, pp. 59-84).

Strategically speaking, Kurucz, et. al recall the business case for CSR as the opportunity for a company to "perform better financially by attending not only to its core business operations, but also to its responsibilities toward creating a better society" (Kurucz, Colbert, \& Wheeler, 2008). They describe four types of the business case for CSR, namely "Cost and Risk Reduction", "Competitive Advantage", "Reputation and Legitimacy", and "Synergistic Value Creation". When discussing the BoP strategies, they consider their business case to be a competitive advantage. They justify that BoP strategies are mostly hold by Western firms entering less developed geographies and for which much of the financial value is captured by the MNC rather than by the populations themselves. In contrast, Halme and Laurila (2009), with their intention to study the outcomes of CSR activities, clearly define the BoP strategies as a "Corporate Responsible Innovation" type, which consists in developing new business models that tackle social and environmental issues. Similarly, Porter and Kramer (2011) precisely describe BoP strategies as a lever for "creating shared value". "Innovation CSR" and "creating shared value" meanings, however are similar to a "synergistic value creation" in the sense that they all describe an opportunity to create value both for the company and the society. The literature focusing on BoP strategies addresses mainly the characteristics of ventures at the field level rather than the broader strategy of the firms undertaking such initiatives. A first attempt to deepen the understanding of value creation captured by companies that implement BoP initiatives has been conducted by Keating and Schmidt (2008) in their case study of 22 MNEs' business units. They reveal three types of opportunities for "Financial gain", "Strategic business improvement", and "Financial, strategic and philanthropic benefits". Companies' representatives cited first the financial benefit in targeting the BoP segment. Their study highlights also secondary benefits, which were not considered critical in the decision to enter BoP markets, but represent valuable impacts such as positive public relations, development of employees' competencies, innovation spreading and organisational restructuring.

First reviews of BoP strategies agreed on distinguishing a "BoP 1.0" and a "BoP 2.0" models (Arora \& Romijn, 2012; Munir, Ansari, \& Gregg, 2010; Perrot, 2010), which respectively adopt a "market capture" approach in order to increase sales and profits, or a "market creation" approach leading to disruptive innovation. Taking stock of the BoP strategies ten years after Prahalad's initial statement shows that the bet made by MNEs is not yet won. Indeed, some of the early initiatives are now relegated to philanthropic department or simply dismantled as the HP's e-Inclusion initiative, SC Johnson's Community Cleaning Services venture, or $P \& G$ and its PuR water purification sachets (Munir, Ansari, \& Gregg, 2010; Simanis \& Milstein, 2012). Those initiatives thus are considered for having failed in reaching sustainability and in demonstrating a business case. However, despite a sensitive context to become economically viable, numerous MNEs continue to invest in $\mathrm{BoP}$ ventures. Among them, we may cite the early examples of Hindustan Lever Ltd and its programme Shakti or Cemex and its Patrimonio Hoy project considered as successful BoP initiatives. The following review of the BoP literature, in line with this dual definition of commercial and societal BoP models, helps us to learn from the successes and failures at the BoP in order to propose what would be an integrated CSR BoP model for MNEs that continue such ventures. Table 1 summarizes our hypotheses towards the emergence of an integrated CSR BoP model. 
Table 1: An integrated CSR BoP model

\section{Integrated CSR BoP model}

\begin{aligned} \hline Strategy & BoP strategy integrated into CSR \\ & strategy \\ - & CSR strategy integrated into the \\ & company's strategy \end{aligned}

Organization - Deeply rooted in local business operations

- Driven by entities close to the top management

$\begin{array}{lll}\begin{array}{l}\text { Corporate } \\ \text { value } \\ \text { creation }\end{array} & - & \begin{array}{l}\text { Indirect business returns } \\ \text { competencies, innovation...) }\end{array} \\ & -\begin{array}{l}\text { Tangible profitability on the mid- } \\ \text { term }\end{array} \\ \begin{array}{l}\text { Societal } \\ \text { value } \\ \text { creation }\end{array} & -\begin{array}{l}\text { Acceptance of product \& solution } \\ \text { from BoP populations }\end{array} \\ & -\quad \begin{array}{l}\text { Acceptance from stakeholders } \\ \text { Social performance monitoring }\end{array}\end{array}$

\subsection{Success and failure of the Commercial BoP model}

The BoP concept was initially built on a commercial lens that calls MNEs to adapt locally in order to grow in untapped markets of low-income consumers (Prahalad \& Hammond, 2002; Prahalad \& Hart, 1999, 2002). We refer to this initial trend as Commercial BoP Ventures.

A notorious example is the Wheel product launched by Unilerver's Indian subsidiary, Hindustan Lever Ltd. (HLL) in late 1990's, which proposed a reformulated detergent sold in single-use package (S. Hart, 2007, pp. 140-145). The company introduced it into an adapted distribution channel of small retailers, making it accessible to low-income population. HLL's initiative was a response to the rapid change of its competitive landscape in India (Perrot, 2010). HLL's goal was to counteract the expansion of Nirma, an Indian leading company in FMCGs that succeeded in reaching rural markets, thus capturing significant market shares. HLL then created the project Shakti to leverage its distribution capacity through a network of women entrepreneurs who sell several brands of the company.

From a theoretical perspective, MNEs are advised to seek for national growth opportunities for which local adaptation can then be transported abroad to similar segments (Prahalad \& Fruehauf, 2004, pp. 50-53). In that sense, Simanis and Milstein (2012) emphasize on inscribing BoP markets - recalled D\&E segments - In the day-today perspective of middle managers at the local scale. This highlights the potential for replicating $\mathrm{BoP}$ ventures among MNEs implementations in different emerging markets. The decentralized organization of Unilever permitted its Indian subsidiary to "fly under the radar" and validate such an innovative business model for the company (S. Hart, 2007, p. 142). Unilever replicated the successful Indian business approach in other markets to develop, for instance, a new detergent dedicated to poor populations in Brazil. However, Hillemann and Verbeke (2014) claim that replicating a "success template" is an illusion in terms of economies of scale due to high costs and uncertainties to transfer competencies developed by MNEs' subsidiaries in each local contexts.

On the corporate value creation side, language used by Prahalad in his seminal book testifies for a deep business rooting when he explains that "the basic economics of the BOP markets are based on small unit packages, low margin per unit, high volume, and high return on capital employed" (Prahalad \& Fruehauf, 2004, p. 24). This equation would lead companies to develop self-sustaining business models for which high volumes of sales would cover investment and exploitation. According to Hart, HLL reached in 2007 a $40 \%$ share of the detergent market in India, and the company "registered a 20 percent growth in revenues per year and 25 percent growth in profits per year for 19931999" (S. Hart, 2007, p. 143). However, selling small packaging in rural areas or urban slums is not the panacea as testify the cases of Procter and Gamble (P\&G) and DuPont. In 2000, P\&G launched PuR, a water purification powder sold in low-cost sachets, thanks to an investment of US $\$ 15$ million to develop the product and test the market (Baddache, 2008). Despite a penetration rate of up to $10 \%$ and a margin of $50 \%$ per sachets, the product could not sell "fast enough to make a positive return". In 2005, P\&G decided to transform the project into a non-profit initiative that would sell the sachets at cost to humanitarian organizations. Six years later, $P \& G$ sold its subsidiary PUR Water Purification Products Inc. but kept the PuR Sachets as part of its Children's Safe Drinking Water corporate philanthropy program $(P \& G, 2011)$. In 2006, Solae, a DuPont's subsidiary, intended to distribute sachets of soy-based proteins that would help fighting malnutrition. The venture realized it could not reach the volume of sales that would ensure profitability and stopped its activities in 2008 (Simanis, 2012). In opposition to HLL's Wheel detergent, Solae's soy proteins and P\&G's PuR sachets would have faced reluctance from consumers to change their habits by using unknown products. 
On the societal value creation side, the BoP concept stipulates that market-based approaches, alongside profit generation for MNCs, will lead to poverty alleviation or broader development for poor populations (Prahalad \& Hart, 1999). Prahalad argues that $\mathrm{BoP}$ populations will benefit from a social and economic transformation thanks to the consumption of an increased choice of products and services provided through market mechanisms. Prahalad provides some cases like the ITC's eChoupal venture providing access to market information for rural Indian farmers through Information and Communications Technologies leading to a greater productivity of plantations and better retail prices. However, his work remains elusive on the way to describe the causal link between market inclusion and social transformation. Some critiques emerged to reject the capacity of selling new products and services to the poor as a relevant poverty alleviation approach (Arora \& Romijn, 2012; Karnani, 2007b; Walsh, Kress, \& Beyerchen, 2005). Simanis and Milstein (2012) reassert that the BoP concept initially focused on poverty alleviation merely as a positive externality of consumption. Over marketing of a product among poor consumers has been also denounced. 'Fair and Lovely' skin whitening face cream - another brand of HLL - has been highly criticized for not serving the broader social welfare and development needs of BoP populations (Munir et al., 2010). Karnani (2007a) testifies the benefit that Indian women are able to purchase this cream as a mean for improved self esteem and liberty of choice. However, his case study reveals that the efficacy of the cream remains doubtful. Moreover, he denounces the marketing strategy of the company, which "serves to entrench [women] disempowerment" and perpetuate sexist and racist prejudices among $\mathrm{BoP}$ and young populations of developing countries. While the Fair \& Lovely brand is a commercial success, NGOs and some Indian government bodies considered that its social impact was negative. HLL's communication on CSR as being part of its "corporate purpose", did not ensured one of their BoP strategy to improve social welfare. In this context, we should consider the societal value creation of a BoP strategy as important as its financial viability, should a company consider it as an integrated part of its sustainable development strategy.

\subsection{Success and failure of the Societal BoP model}

A second set of the literature emphasized on the societal strategic role of $\mathrm{BoP}$ concept with a focus on poverty alleviation and development impacts of business ventures. This led to the distinction of a
"BoP 2.0" approach refining early statements and taking into account its criticisms (Ansari, Munir, \& Gregg, 2012; S. Hart, 2007). The paradigm of the BoP concept shifted with the "BoP protocol" towards its capacity to economically empower BoP populations through skill building in a bottom-up approach (Simanis \& Hart, 2008). We will refer to this model as Societal BoP Ventures.

Another notorious example is the e-Inclusion initiative, launched in 2000 by Hewlett-Packard (HP) to empower BoP populations through enabling access to Information and Communication Technologies (ICT) (Traça \& Foryt, 2004). "Inclusive communities" were first launched in 2002 in South Africa and in Andhra Pradesh, India. These so-called i-communities projects deployed ICT technologies to sustain socio-economic development and served as an experimental platform for HP to test new solutions and business models. The approach was considered exemplary in terms of "relationship building, empowerment, and deep involvement with the BoP" (Ansari et al., 2012). Motivations for HP were clearly stated from the beginning: e-inclusion would permit the company to create new markets, leading to growth in revenue and profit especially in emerging markets, while demonstrating their commitment towards the society (Matambanadzo, 2001). As emphasized by Traça and Foryt (2004), key stakeholders of e-inclusion were the local communities and the governments. HP's efforts would then lead to improve its public relations. In 2005, the e-inclusion initiative withdrew from the company's CSR agenda when HP's direction changed. Entrepreneurship and micro-enterprise development then continued to receive support from HP's philanthropy programs.

From a theoretical perspective, such BoP approaches focuses on cross-sector partnerships as a key condition to create markets at the Base of the Pyramid (Murphy, Perrot, \& Rivera-Santos, 2012; Reficco \& Márquez, 2012; Rivera-Santos \& Rufín, 2010). Non-governmental organisations (NGOs), social entrepreneurs, and the BoP populations themselves have been identified by some authors as key stakeholders in reaching population needs and providing acceptance of new products or services thanks to their anchorage in social and cultural systems (Brugmann \& Prahalad, 2007; London \& Hart, 2004; Seelos \& Mair, 2007). Internally speaking, societal ventures require patient capital and long-term commitment from the company (Karamchandani, Kubzansky, \& Lalwani, 2011; Kennedy \& Novogratz, 2011). The BoP Protocol similarly advises companies to set an 'R\&D "White Space" (Simanis \& Hart, 2008). Close to the top management team, such ventures can operate 
outside traditional business metrics and processes either by the creation of a new external venture to the company or by its internal management from a dedicated corporate functional department (London, 2010). However, a first reason for HP's failure lies in the fact that the company was incapable of absorbing into its broader organisation and strategy what appeared to be solely a CEO-driven program (McFalls, 2007). E-Inclusion suffered from a topdown management, in which the corporate initiative pushed for decisions within the local project group without implying the South African subsidiary. The program also lied in an emotional promise to serve sustainably the world's billion poor, highlighting a disconnect with a business rationale of the company (Simanis \& Milstein, 2012).

On the corporate value creation side, societal $\mathrm{BoP}$ ventures are intended to lead to the next unexplored revenue streams by capitalizing on innovation learning as a lever for reverse innovation for mature markets (Faivre-Tavignot, 2012; FaivreTavignot, Lehman-Ortega, \& Moingeon, 2010). Other authors insist on the construction of companies ethical positioning when they need to embed "moral capacities" (Cholez, Trompette, \& Vinck, 2010) and position themselves as "corporate citizens" (Hahn, 2009, 2012). However, the economic sustainability - not to mention the profitability - remains a primary criterion of success. A second reason for HP's withdrawal of the e-inclusion initiative resides in the fact that a shortterm commitment frustrated the operational teams whom had to achieve results within a period of three years (Schwittay, 2011). The new CEO terminated e-Inclusion as part of broader cost-cutting measures. He considered that the initiative had not demonstrated sufficient returns on investments, and that solutions created for the BoP market could cannibalize traditional business (McFalls, 2007). SC Johnson experience in Kenya is another example of a BoP initiative that did not lead to the promised economic results. The Community Cleaning Services (CCS) venture was one of the flagship of the BoP Protocol (Simanis \& Hart, 2008), aimed at improving urban sanitation by involving young disadvantaged populations from slums. While the venture was considered as a success in meeting the expectations of local stakeholders, its microfranchises business model could not reach a financial performance that would justify further business investment (Thieme \& DeKoszmovszky, 2012). The venture transitioned into a local external non-profit initiative relying on donations. SC Johnson capitalized on this pilot project and is currently deploying a new business venture in Ghana, tackling malaria infections through mosquito control products. Simanis states that "The project is part of the company's broader social mission"(Simanis, 2012), yet highlighting the integration of $\mathrm{BoP}$ strategies within the broader strategy of the company.

Tracking social changes is not traditional for MNEs but rather used by development institutions or NGOs. Some authors (Ansari et al., 2012; Crabtree, 2007) even called for taking into account the multidimensionality aspect of poverty or the capabilities of low-income people in the sense of Sen (1992).This shift in paradigm opened a part of the BoP literature studying new metrics of tracking social impact performance of ventures for lowincome populations, behind the sole analysis of direct sales (Clay, 2005; London, 2008). In opposition, Simanis and Milstein (2012) argued more recently that internal business performance metrics should be used as a proxy for the targeted social outcome. As an illustration, they use "units of mosquito repellent products sold" as one of the best metric by which to evaluate the contribution of SC Johnson's BoP venture to its broader social objective of preventing malaria contraction (Simanis \& Milstein, 2012).

\section{Empirical strategy and data}

\subsection{Research design and case selection}

Eisenhard and Graebner refer to Edmondson and McManus to explain that theory-building research using cases typically answers research questions that address the "how" and the "why" in unexplored research areas particularly well (Eisenhardt \& Graebner, 2007). This approach also helps to reduce researcher biases and to increase the chance to build empirically valid theories (Eisenhardt, 1989). In the following, we apply our hypotheses to answer the research question of why and how MNEs continue to invest in uncertain contexts of BoP markets. Multiple-case study provide a systematic analysis of complex causal links in presence of numerous different factors (Yin, 1994), which is of particular importance when reviewing BoP strategies that have been already studied in the past literature, alongside new ones that we present in our study.

As defined by Yin (Yin, 2009, pp. 29-33; 2012, pp. 6-7), we selected multinational enterprises and their BoP initiatives as the main "unit of analysis" of the cases. For that purpose, we analyze seven MNEs which have already established business activities targeting BoP populations and which, at the time of the study, maintained their investments to develop the internal initiatives that support them. To select cases, we focused on diverse activities in order to reveal more information than average or similar cases (Eisenhardt \& Graebner, 2007) and which 
will guarantee heterogeneity. Companies were selected based on their role in the domain of BoP strategies (i.e. leadership), the diversity of their industry (i.e. cross sector), their modality of operations (i.e. different business models) and their geographies of intervention (i.e. cross country). Selected companies are Danone and its danone.communities fund and its former $B o P$ Business Unit; Electricité de France (EDF) and its Access to Energy mission; Essilor and its New Vision Generation division; Grundfos and its Lifelink department; Lafarge and its Affordable Housing programme; Schneider Electric and its BipBop programme; and Veolia and its former Acces methodology and its newly established Innove division. The cases span different industries, proposing fast-moving consumer goods (FMCGs), durable goods or infrastructures solutions. Within each company, projects implemented may be numerous. Therefore this paper is positioned as an embedded, multiple-case study as defined by Yin (Yin, 2009, pp. 46-60; 2012, pp. 7-9), where field projects constitute the sub-cases. Within each company's initiatives, projects were selected in agreement with company representatives. Table 2 gives an overview of the selected companies' BoP initiatives and their related projects.

\subsection{Data collection and method of analysis}

We collected data for our case studies from multiple sources. We gathered information from secondary sources as institutional documents, communication-oriented documents and press releases from companies, professional reports from consultants, company consortiums or international agencies, as well as previous cases from articles in academic journals, theses and books. In addition, we conducted 10 interviews with company representatives both at headquarter and at local operations to complete the information in regards to our research question. The position of the author as an "insider" (Brannick \& Coghlan, 2007) within the BoP industry also helped to select companies and identify key representatives who manage or actively take part in inclusive business initiatives. Companies and interviewees were identified after a 3 -year period of participative observation within the BoP industry (January 2010-December 2012), conducted as a project manager of a $\mathrm{BoP}$ initiative in a French Multinational Enterprise specialized in energy management. The author participated in many formal meetings held by think-tanks, working groups, research workshops and conferences, or business meetings with MNEs, consultants, NGOs, Micro Finance Institutions (MFIs) and international agencies. The author also participated in many informal discussions with people working in entities cited above. This position, described by Adler and Adler as an "active member" let the author assume "a functional role in addition to the observational role", which facilitated to build "trust and acceptance of the researcher" (Adler \& Adler, 1987).

Semi-structured interviews lasting between 45 minutes to 1 hour and 30 minutes were conducted between July and November 2013, mainly on a face-to-face basis with some over phone due to geographical distance of companies. Interviews were based upon a semi-structured questionnaire, which has been previously sent to participants. After an introductory phase to review strategic and organizational considerations about BoP initiative within the corporation, all interviewees were asked about the initiative they are managing or working in, and on specific projects that are either maintained or stopped. All of the interviews were immediately recorded, synthetically transcribed, reviewed and edited. At the end of each interviews, a selection of 1 to 5 projects related to the initiative were selected in order to send a survey questionnaire to local managing directors or the projects. The selected projects aim at being representative of the activities of the company in the field of BoP strategies. Questionnaires sent to local managers are structured in two parts, mostly composed of Multiple-Choices Questions, derived from the analysis of the literature review. A first set of questions focuses on the (1) implementation aspects of the projects by covering: its position and links with the company's organization, its relation to $\mathrm{BoP}$ populations and external stakeholders, its degree of innovation applied, and the economic sustainability of the projects. The second set of questions targets the (2) observed results of the projects by covering: the scale and stage of the projects, the types of internal metrics used (both financial and extra-financial), the actual targeted socio-economic segments, and the returns that the company experienced during its lifetime. Quantitative data acquired through the questionnaires were then compiled into a spreadsheet application for statistical descriptive purpose and further analysis. Triangulation was performed thanks to interviews at the corporate level as well as secondary data. 
Table 2: Overview of Companies' BoP initiatives and their field projects

\begin{tabular}{|c|c|c|c|c|c|}
\hline $\begin{array}{l}\text { Company } \\
\text { Name }\end{array}$ & Industry & $\begin{array}{l}\text { Names of } \\
\text { BoP initiatives }\end{array}$ & $\begin{array}{l}\text { Year of first } \\
\text { project }\end{array}$ & BoP projects geographies* & Activities in BoP projects \\
\hline Danone & $\begin{array}{l}\text { Food and } \\
\text { beverage }\end{array}$ & $\begin{array}{l}\text { - BoP Business } \\
\text { Unit } \\
\text { - danone. } \\
\text { communities }\end{array}$ & 2005 & $\begin{array}{l}\text { Bangladesh, Cambodia, China, France, India, } \\
\text { Indonesia, Mexico, Senegal }\end{array}$ & $\begin{array}{l}\text { - Development of enriched dairy products or bottled water distributed in low-income areas } \\
\text { through dedicated distribution channels } \\
\text { - Financial and technical support to social businesses in the dairy or water sector. }\end{array}$ \\
\hline EDF & Electric utility & $\begin{array}{l}\text { Access to } \\
\text { Energy }\end{array}$ & 1999 & $\begin{array}{l}\text { Botswana, Laos, Mali, Morocco, }, \underline{\text { Senegal, }} \\
\text { South Africa }\end{array}$ & $\begin{array}{l}\text { - Investment in and support to Rural Electricity Service Companies (RESCOs) to deliver access to } \\
\text { energy to rural areas through products or small-scale infrastructures } \\
\text { - Contributes to communities electrification in the scope of big infrastructures contracts }\end{array}$ \\
\hline Essilor & Eyeglasses & $\begin{array}{l}\text { New Vision } \\
\text { Generation }\end{array}$ & 2006 & Brazil, China, India, Indonesia & $\begin{array}{l}\text { - Formerly, creation of optometrists vans performing in-situ vision consultation and eyeglasses } \\
\text { manufacturing in rural areas of India. } \\
\text { - At present, development of standardized lenses and frames being distributed through networks } \\
\text { of rural entrepreneurs or alternative channels. }\end{array}$ \\
\hline Grundfos & $\begin{array}{l}\text { Pump } \\
\text { manufacturer }\end{array}$ & $\begin{array}{l}\text { Grundfos } \\
\text { Lifelink }\end{array}$ & 2007 & $\begin{array}{l}\text { - Eastern Africa (Ethiopia, Kenya, Malawi, } \\
\text { Tanzania, Uganda, Zambia) } \\
\text { - Western Africa (Burkina Faso, Ghana, } \\
\text { Nigeria) } \\
\text { - South-eastern Asia (Thailand) }\end{array}$ & $\begin{array}{l}\text { - Development of solar pumping systems integrating a mobile-based prepayment solution, and } \\
\text { deployed through partnerships with NGOs, water utilities or governments } \\
\text { - Pumping system components and services provider to NGOs, water utilities or governments }\end{array}$ \\
\hline Lafarge & $\begin{array}{l}\text { Building } \\
\text { materials }\end{array}$ & $\begin{array}{l}\text { Affordable } \\
\text { Housing }\end{array}$ & 2008 & $\begin{array}{l}\text { Bangladesh, Brazil, Cameroon, Honduras, } \\
\text { France, India, Indonesia, Kenya, Morocco, } \\
\underline{\text { Nigeria, Philippines, Serbia, Sri Lanka, }} \\
\underline{\text { Zambia }}\end{array}$ & $\begin{array}{l}\text { - Development and implementation of distribution networks of housing materials in connection } \\
\text { with microfinance services dedicated to the extension of houses or shops } \\
\text { - Rehabilitation of slums } \\
\text { - Social housing programs with real-estate developers and governments } \\
\text { - New generation social housing projects in developed countries }\end{array}$ \\
\hline $\begin{array}{l}\text { Schneider } \\
\text { Electric }\end{array}$ & $\begin{array}{l}\text { Energy } \\
\text { management }\end{array}$ & BipBop & 2009 & $\begin{array}{l}\text { Bangladesh, Benin, Brazil, Burkina Faso, } \\
\text { Cameroon, Chad, DR Congo, Egypt, Ghana, } \\
\text { India, Madagascar, Nigeria, Peru, Philippines, } \\
\text { Senegal, South Africa, Thailand, Vietnam, } \\
\text { Zimbabwe }\end{array}$ & $\begin{array}{l}\text { - Investment in SMEs in the sector of access to energy } \\
\text { - Development of energy access products and small-scale infrastructures deployed in rural areas } \\
\text { through partnership with dedicated distributors and MFIs or through tenders or contracts with } \\
\text { governments } \\
\text { - Creation of training in energy trades through sponsorship to non-profit organisations }\end{array}$ \\
\hline $\begin{array}{l}\text { Veolia } \\
\text { Environne } \\
\text { ment }\end{array}$ & $\begin{array}{l}\text { Environmental } \\
\text { services }\end{array}$ & $\begin{array}{l}\text { - Acces } \\
\text { - Innove }\end{array}$ & 2002 & $\begin{array}{l}\text { Bangladesh, Colombia, Ecuador, Gabon, } \\
\text { India, Morocco, Mexico, Niger }\end{array}$ & $\begin{array}{l}\text { - Contracts with local authorities combining technical support (Optimization of existing } \\
\text { infrastructures and standpipes), financial and economic support (development of socially } \\
\text { acceptable pricing policies and individuals socially assisted connections), and services and } \\
\text { administrative support creation of community management organizations or mobile sales offices) } \\
\text { - Development and implementation of a small-scale water treatment facility, which treated water } \\
\text { is distributed to local rural communities through direct connexion or to urban areas through } \\
\text { bottles }\end{array}$ \\
\hline
\end{tabular}

\footnotetext{
* Underlined projects' geographies have been studied through a complementary survey questionnaire
} 


\section{Cross-case analysis}

\subsection{Corporate strategies towards the BoP segment}

Three types of strategic engagement towards the BoP segment...

All the studied companies testify for a deep integration of sustainable development stakes into their core activities. While most of them integrated first environmental concerns into business considerations, societal issues and community engagement emerged primarily through philanthropic activities and charitable actions. When it comes to developing sustainable business models that address social issues faced by the Base of the Pyramid populations, the seven companies testify for an extension of their core activities influenced by their Corporate Social Responsibility as well as a leadership position in their respective industries. Every management team will carry the voice of their responsibility concerns within the overall strategy of the company. In that sense, companies appear to have adopted Davidson's recommendation, who urged MNEs to incorporate the core elements of CSR into the BoP concept (Davidson, 2009). However, we may notice three different ways of engaging the overall strategy of the companies towards the BoP segment through: dedicated sustainable development policies; commitments on results at the $\mathrm{BoP}$ segment; or a strategic repositioning of the firm. These three types of engagement highlight an extension of the boundaries within which companies' strategies are contributing on a business basis to tackle societal issues faced by the Base of the Pyramid.

First, companies like EDF and Veolia Environnement will stipulate their engagement through dedicated sustainable development policies to settle a BoP initiative, shared between the direction and its stakeholders. Secondly, companies like Lafarge and Schneider Electric will commit further by establishing dashboards to report externally on the progress of their sustainable development plans, which include global objectives on their BoP initiative. Third, companies like Danone, Essilor and Grundfos will reposition their company strategy by specifically addressing the societal issue of targeting the lowest socio-economic segments. Table 3 provides the evidence of these three types of CSR strategic engagement towards the BoP market. The appendix summarizes each of the seven company cases.

\section{...based on three different business rationales}

When targeting markets at the Base of the Pyramid, all companies' representatives report for their progressive building of a business case towards their direction in order to justify their investment. Depending on the firms' CSR strategy, BoP initiatives will receive the mandate to create both direct and indirect business results, as well as to capture short, midterm or long-term corporate returns for the company. Interviews with corporate managers and directors reveal three business rationales for their BoP initiatives, which mainly aim at gaining legitimacy; incubating strategic change; or reaching profitable growth. Table 4 depicts the three business rationales of the studied BoP initiatives.

\section{- Gaining legitimacy}

Projects providing access to basic needs related to public services as energy and water evolve in a regulated environment and require significant investments. This implies often to deal with authorities and regulatory entities. EDF investments and support for the construction of local Rural Electricity Service Companies improve its relations with government bodies. A stakeholder management approach helps to align with their expectations. Companies gain their licence-to-operate through an improvement of their reputation. One of the managers of Veolia Environnement explains that the competencies acquired through project experimentations within contracts can help to prevent reputational risks and demonstrate to future customers that innovative solutions can be applied to serve every socio-economic segment. In the context of BoP strategies, business environments also present limitations in terms of legal mechanisms or infrastructures. Adaptation to such sensitive local contexts represents a mean to develop new capabilities for corporations among their industries (Mary, 2013). In a general perspective for Veolia Environnement, access to essential needs is also a competitive advantage stake. The company's position of public service delegation means that everyone has to be targeted with a single tariff. One of its managers clearly mentions the development of a "strategic differentiation" and an "economic value added", which both help to win new types of contracts and tenders. Similarly, EDF's initiatives accompany business operations that are in charge of big infrastructures projects or peri-urban electrification programmes to include a social clause to the contracts.

\section{- Incubating strategic change}

By essence, incubating projects and business models implies translating them into recurrent or long-lasting opportunities. Innovation is at the heart of such business rationale. 
Table 3: three types of CSR strategic engagement towards the BoP segment

\begin{tabular}{|c|c|c|}
\hline $\begin{array}{c}\text { Strategic } \\
\text { engagement }\end{array}$ & Company & Source \\
\hline $\begin{array}{c}\text { Sustainable } \\
\text { development } \\
\text { policies }\end{array}$ & $\begin{array}{l}\text { EDF } \\
\text { Article } 16 \text { of the "Agreements on EDF Group Corporate Social Responsibility": } \\
\text { - "The signatories consider that access to energy is a major factor in social and economic } \\
\text { development and a key factor in the fight against poverty." } \\
\text { - "EDF Group and its component companies take initiatives or support initiatives through } \\
\text { partnerships in various countries, in particular in regions where they are based, to promote better } \\
\text { access to energy for communities." } \\
\text { Veolia Environnement } \\
\text { Commitment } 11 \text { of the sustainable development charter: } \\
\text { - the company "contribute to local economic and social development and to meeting international } \\
\text { goals for access to essential services" }\end{array}$ & $\begin{array}{c}\text { (Veolia } \\
\text { Environnement, } \\
\text { 2013, pp. 19-25) }\end{array}$ \\
\hline $\begin{array}{l}\text { Commitments } \\
\text { on results at } \\
\text { the BoP }\end{array}$ & $\begin{array}{l}\text { "Sustainability ambitions for 2020": } \\
\text { - The Affordable Housing programme will have to "enable } 2 \text { million people to have access to } \\
\text { affordable and sustainable housing" } \\
\text { "Planet \& Society Barometer", renewed every three years. For the period 2009-2014, the company } \\
\text { committed: } \\
\text { - } \quad \text { to provide access to energy on a sustainable basis to a cumulative two million people; } \\
\text { and to train in energy trades a cumulative of } 30000 \text { people. }\end{array}$ & $\begin{array}{l}\text { (Schneider } \\
\text { Electric, 2011, p. } \\
\text { 2; 2013, p. 6) }\end{array}$ \\
\hline $\begin{array}{c}\text { Strategic } \\
\text { repositioning } \\
\text { of the firm }\end{array}$ & $\begin{array}{l}\text { Danone } \\
\text { In } 2003 \text {, the company's slogan changed from "bringing health through food" to "bringing health } \\
\text { through food to as many people as possible." } \\
\text { Essilor } \\
\text { In } 2005 \text {, new responsible mission has been "to preserve and correct the eyesight of each and every } \\
\text { person, around the world", reasserted in } 2006 \text { with their mission "to enable as many people as possible } \\
\text { to see the world better." } \\
\text { Groundfos } \\
\text { In } 2008 \text {, the Group will commit with a "framework of shared value" for both the company and the } \\
\text { society. } \\
\text { "Company purpose": "We contribute to global sustainability by pioneering technologies that improve } \\
\text { quality of life for people and care for the planet". It specifies that the Group is "always eager to find } \\
\text { solutions for the world's most poverty-stricken communities and people with special needs." }\end{array}$ & $\begin{array}{l}\text { (Faivre-Tavignot } \\
\text { et al., 2010) } \\
\text { (Essilor, 2006; } \\
\text { 2007, p. 3) }\end{array}$ \\
\hline
\end{tabular}

Table 4: three business rationales of BoP initiatives

\begin{tabular}{|c|c|c|c|}
\hline & Gaining legitimacy & Incubating strategic change & Reaching profitable growth \\
\hline $\begin{array}{l}\text { BoP initiatives' } \\
\text { Business results }\end{array}$ & $\begin{array}{l}\quad \text { Indirect }<-\cdots-- \\
\text { - Contracts or tenders won } \\
\text { - Public relations }\end{array}$ & $\begin{array}{l}\text { Products and business } \\
\text { innovation } \\
\text { - Reputation }\end{array}$ & $\begin{array}{l}--->\text { Direct } \\
- \text { Sales increase }\end{array}$ \\
\hline $\begin{array}{l}\text { Company } \\
\text { returns }\end{array}$ & $\begin{array}{l}\quad \text { Mid-term } \\
\text { - Licence-to-operate } \\
\text { - Competitive advantage }\end{array}$ & $\begin{array}{l}\quad \text { Long-term } \\
\text { - Business screening } \\
\text { - Strategic renewal }\end{array}$ & $\begin{array}{l}\text { Short-term } \\
\text { - Profitability } \\
\text { - Market share }\end{array}$ \\
\hline $\begin{array}{l}\text { Focal point of } \\
\text { value creation }\end{array}$ & Stakeholders & Corporation & Shareholders \\
\hline $\begin{array}{l}\text { CSR strategy } \\
\text { towards the BoP }\end{array}$ & $\begin{array}{l}\text { Sustainable development } \\
\text { policies }\end{array}$ & $\begin{array}{l}\text { Commitments on results at the } \\
\text { BoP }\end{array}$ & $\begin{array}{l}\text { Strategic repositioning of the } \\
\text { firm }\end{array}$ \\
\hline $\begin{array}{l}\text { Examples of } \\
\text { BoP initiatives }\end{array}$ & $\begin{array}{l}\text { - EDF: access to energy mission } \\
\text { - Veolia Environnement: former } \\
\text { Acces methodology }\end{array}$ & $\begin{array}{l}\text { - Danone: danone.communities } \\
\text { fund } \\
\text { - Lafarge: Affordable Housing } \\
\text { programme } \\
\text { - Schneider Electric: BipBop } \\
\text { programme } \\
\text { - Veolia Environnement: new } \\
\text { Innove division } \\
\text { - Grundfos: former Lifelink } \\
\text { venture }\end{array}$ & $\begin{array}{l}\text { - Essilor: new Vision } \\
\text { Generation division } \\
\text { - Grundfos: new Lifelink } \\
\text { business unit } \\
\text { - Danone former BoP business } \\
\text { unit }\end{array}$ \\
\hline
\end{tabular}


Societal engineering is addressed primarily during the early development stage of BoP initiatives by developing dedicated products and adapted business models. danone.communities built metrics to evaluate the successfulness of their social intervention. Its managing director explains that the key performance indicators they use "continue to make traditional business men smile". Lafarge's manager testify for a double societal and economic purpose with both the 2020 CSR ambitions of the Group with societal objectives that are communicated externaly (Lafarge, 2012) and an internal commercial plan running until 2015 with operating income objectives. BoP initiatives will then focus on their economic sustainability in order to make profit or at least to reach the break-even. In that sense, Danone's representative reminds, "Social Business is business". At the time of writing this paper, the managers of Schneider Electric were studying the potential to consider BipBop as a line of business regarding its commercial activity. The potential for BoP initiatives to reach scale in terms of sales or to become a customer value proposition on its own appear to be the determining criteria that will be assessed by management teams to decide whether they can evolve towards a mainstream business activity.

- Reaching profitable growth

BoP strategies becoming new growth avenues for multinationals remain a central question within BoP initiatives. The assumption of potential profit generation that can be directly attributed to BoP strategies has been widely accepted by companies' consortiums and analysts (Mary, 2013; Natixis, 2012; SNV \& WBCSD, 2008). Such a bet has already been taken at Grundfos and Essilor. In that case, objectives of BoP initiatives are mainly commercial ones. KPIs intend to reveal the mass phenomenon that companies are trying to reach. As an illustration, Essilor sales objectives within the New Vision Generation division will try to reach 46 million people per year by 2020 , representing a present market share of $10 \%$. Both Essilor and Grundfos' initiatives differentiate by their market approach focusing on lower socio-economic segments as an end-customer group recognized by the company.

\section{Evolving strategies?}

We may notice that BoP initiatives may adopt a trajectory that will make evolve their strategy and thus their business rationales. In that sense, a gaining legitimacy approach could lead to incubating strategic change, potentially leading to a business rationale aimed at reaching profitability. Directions of some companies reconsidered positively the value that they can generate for the company. As an illustration, Veolia started by creating the "Acces" methodology led by the Sustainable Development direction, which took stock on the several field contracts that integrated a social engineering clause meant to serve the BoP populations. At the time of writing this paper, this supportive approach towards business operations was being translated into a more top-down approach. The new "Innove" division, being settled within the Market Innovation executive direction, would now be in charge of developing social innovation projects at the field level with the support of local operations, before transferring acquired competencies and expertise to more traditional business units. Similarly in the case of Lafarge, pilot projects in social housing programmes in agreement with local authorities and real-estate developers contributed to the shift in the management team perception of BoP markets as a potential business opportunity rather than a publicrelation mean (Perrot, 2011, pp. 85-87). The cases of Essilor and Grundfos illustrate the adoption of a stronger profitable business rationale as they both recently translated their incubating projects into protected lines of businesses. However, we do not pretend that reaching profitable growth is an end for BoP initiatives. Companies may well valorise other indirect business returns. In that sense, danone.communities managing director stipulates that the fund "is a laboratory to reach the greatest number of people, and that's it". Similarly, the EDF initiative has been granted a responsible mandate to contribute to access to energy with a mean to improve the company's relations with local authorities, or support local operations to include a social clause in contracts or tenders.

\subsection{Organization and observed results}

\section{Implementing projects}

In order to operationalize their strategies towards BoP segments, companies developed dedicated initiatives. They all affiliate to corporate directions, which are themselves closely related to or part of the executive committees of each company. The closeness with company Executive will give the initiatives the mandate to develop market approaches based on their own rules. In accordance with London's case study (2010), dedicated BoP entities aim at protecting the field projects from the influence of traditional metrics and processes. Interviews at the corporate level crossed with questionnaires at the field level help us to identify three ways to operationalize $\mathrm{BoP}$ projects or 
ventures depending on the strategy that the company

adopted.

Table 5 depicts the ways of implementing BoP initiatives and their projects.

Table 5: ways of implementing BoP initiatives and projects

\begin{tabular}{|c|c|c|c|}
\hline & Gaining Legitimacy & Incubating strategic change & Reaching profitability \\
\hline $\begin{array}{l}\text { Organization of } \\
\text { the BoP initiative }\end{array}$ & $\begin{array}{l}\text { Transversal corporate } \\
\text { function }\end{array}$ & Incorporated function & Dedicated vertical business \\
\hline $\begin{array}{l}\text { Role of the BoP } \\
\text { initiatives }\end{array}$ & $\begin{array}{l}\text { Support local operations or } \\
\text { create external venture }\end{array}$ & $\begin{array}{l}\text { Integrate with company's support } \\
\text { functions \& local operations }\end{array}$ & Operate autonomously \\
\hline $\begin{array}{c}\text { Relation with local } \\
\text { business } \\
\text { operations }\end{array}$ & $\begin{array}{l}\text { Bottom-up: } \\
\text { Answer to the needs of } \\
\text { decentralized business units } \\
\text { or stakeholders }\end{array}$ & $\begin{array}{c}\text { Top to bottom } \\
\text { With strong involvement of } \\
\text { countries' direction and } \\
\text { operations }\end{array}$ & $\begin{array}{l}\text { Independent: } \\
\text { Take advantage of the local } \\
\text { brand recognition and market } \\
\text { penetration }\end{array}$ \\
\hline $\begin{array}{c}\text { Example of field } \\
\text { projects* }\end{array}$ & 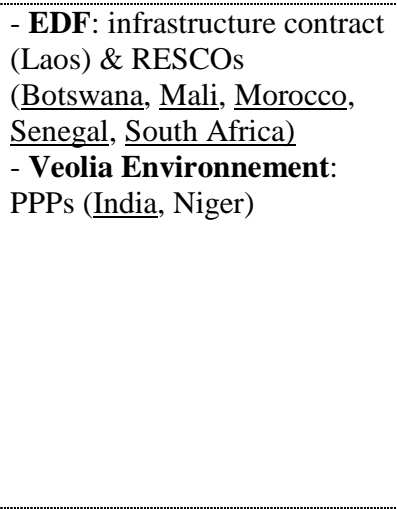 & $\begin{array}{l}\text { - Danone: social businesses } \\
\text { (Bangladesh, India, Mexico, } \\
\text { Senegal) } \\
\text { - Lafarge: affordable housing } \\
\text { business (Cameroon, Honduras, } \\
\text { India, Indonesia, Kenya, Nigeria, } \\
\text { Philippines, Zambia...) } \\
\text { - Schneider Electric: access to } \\
\text { energy business (Bangladesh, } \\
\text { Brazil, Cameroon, Egypt, India, } \\
\text { Nigeria, Philippines, Senegal, } \\
\text { South Africa, Vietnam...) } \\
\text { - Veolia Environnement: social } \\
\text { business (Bangladesh) }\end{array}$ & $\begin{array}{l}\text { - Essilor: New Vision } \\
\text { Generation division (Brazil, } \\
\text { China, India, Indonesia) } \\
\text { - Grundfos: Lifelink business } \\
\text { unit (Eastern Africa, Western } \\
\text { Africa, South-eastern Asia) }\end{array}$ \\
\hline Barriers to grow & $\begin{array}{l}\text { - Projects' scale limited by } \\
\text { nature } \\
\text { - Rely on awareness of social } \\
\text { stakes from operations }\end{array}$ & $\begin{array}{l}\text { - Start-up positioning potentially } \\
\text { marginalized from local business } \\
\text { stakes } \\
\text { - Require adoption from support } \\
\text { functions (HR, marketing, R\&D, } \\
\text { logistics...) }\end{array}$ & $\begin{array}{l}\text { - Sensitive to short-term } \\
\text { financial results objectives }\end{array}$ \\
\hline
\end{tabular}

The 17 projects studied at the field level are implemented either by internal business operations of companies or by external ventures in which the BoP initiative or the company has stakes. Half of the projects, which are implemented by Essilor, Grundfos, Lafarge, Schneider Electric and Veolia, rely on local operations with an average of 4 to 5 employees who are managing them. The other half are managed by local associations or private companies as in the case of danone.communities projects, EDF's RESCOs and Grameen Veolia Water Ltd joint venture between Veolia Eau and Grameen Healthcare.

The decentralized management of the projects ensures their adaptation to the local contexts and markets it targets. The fact that BoP project managers are part of the companies' local team will ensure a greater support from traditional business operations. In most of the cases, this is accompanied with an implication of local country presidents who discuss their evolution but also track their results. The role of the corporate team of the BoP initiatives however remains central for all the projects. Indeed, they will act as a back-office for legal, financial and technical issues and facilitate the contribution from support functions of the multinationals in terms of $\mathrm{R} \& \mathrm{D}$, industrialization, marketing, HR or logistics. The BoP initiatives are also in charge of defining the strategy and fixing the financial and social objectives either directly or through their presence in the board of external ventures. Moreover, their position within the company's hierarchy helps to initiate discussions and attract international partners as NGOs or financial institutions in the development sector.

\section{From results tracking to accountability}

Considering the seniority of the projects, their compared results testify for an increase of customers reached per year, highlighting the capacity for the oldest ones to scale-up their activities on the long run. BoP initiatives will progressively develop deeper metrics to track both financial and societal results. Table 6 depicts the evolution of the use of financial and societal metrics per the seniority of the projects. 
Table 6: evolution of the use of financial and societal metrics, per seniority of the projects

\begin{tabular}{lcc}
\hline Seniority of projects: & $<\mathbf{3}$ years & $>$ 3 years \\
\hline Use of financial metrics: (number and \% of projects) & \\
Revenue/sales & $10(100 \%)$ & $7(100 \%)$ \\
P\&L, or financial ratios (RoI, RoE, RoA...) & $4(40 \%)$ & $7(100 \%)$ \\
\hline Use of societal metrics: (number and \% of projects) & $9(90 \%)$ & $7(100 \%)$ \\
Number of customers or entrepreneurs reached & $3(30 \%)$ & $4(57 \%)$ \\
Social performance indicators & $4(40 \%)$ & $5(71 \%)$ \\
\hline Social impact evaluation (experimental or non-experimental) & 4 \\
\hline
\end{tabular}

In terms of financial results, scale remains a critical factor to assess the success of a project. All of the projects are tracking basic business metrics as quantities sold, revenues and number of customers. This is in line with Kolk et al. (2012) review of BoP literature in which the majority of measures reported in the papers relate specific figures as price, cost, revenue, margin, market penetration or number of customers. However, analysis of projects answers to the questionnaires reveal that the more the projects are old, the more P\&L statements or financial ratios will be used for assessing the economic sustainability of the projects. This is particularly true for external ventures that can intrinsically rely less on internal subsidies from the company to support the losses.

When it comes to the social objectives of the projects, they all testify for reporting basic metrics as the number of customers and communities reached or the number of micro entrepreneurs involved in the model. Yet, the definition of the poverty level of targeted populations rarely go further than a wide designation or specific categories as rural women or slum inhabitants. Let us note, though, some models implying microfinance or policies of social tariffs that actually track income thresholds of the endcustomers to determine their eligibility at the intervention. In terms of broader societal change induced by the projects, more than a half declared for having performed social impact evaluations. This is notably the case for almost all of the oldest projects as well as for three quarters of the projects managed by an external venture. Being accountable towards social value creation appears to be determinant for projects relying on public and international development funding or for $\mathrm{BoP}$ initiatives that communicates on their responsibility.

Looking back at the business rationales of BoP initiatives, direct profit generation from $\mathrm{BoP}$ projects has been acknowledged as potential, but uncertain. Only three projects studied onto seventeen report for generating profit, while more than a half is still in a process of reaching the break- even. External subsidies may also contribute to the economic sustainability of the projects as in the case of the former EDF's RESCO, Kurayé Kurumba, in Mali that faced an increase of its operating expenses due to the volatility of the price of oil. Our interviews reveal that companies also recognize the capacity of BoP initiatives to capture indirect financial benefits or even extra-financial returns. Such benefits span from the most tangible to the most intangible ones (Mary, 2013; Natixis, 2012; SNV \& WBCSD, 2008). Project managers, on their side, testify for improved relationships with traditional business partners in half of the cases, especially for the ones managed internally. Image improvements also attracted new customers for half of the projects, while it is a critical mean for all the projects built in partnership with local authorities. In terms of human resources, project managers report for an increase of the engagement, motivation and pride of local employees, as well as the development of new competencies for their collaborators involved in projects' implementation. In terms of a broader strategic change of firms, BoP field operations at Essilor and Grundfos recognize a shift in the company strategy, which is in line with the recent creation of dedicated business units focusing on this new segment. However, almost none of the initiatives and projects reported for a performance tracking of such indirect financial benefits and extra-financial returns related to reputation, image, human resources or innovation on which the company would capitalize for its traditional business and broader strategy.

\section{Conclusion}

Traditional prejudices against case study method rely on the little ability to generalize scientifically the findings (Yin, 2009, pp. 14-16). We acknowledged that the findings are uniquely tied to the company cases we studied. The fact that most of the companies studied are headquartered in France may imply a potential bias in terms of geographic concentrations of interconnected companies 
(Michael Porter, 2000). However, the multiple case study analysis of seven BoP initiatives demonstrated a replication of the same phenomenon under diverse conditions like the companies' industries (FMCGs, water, energy, housing) and therefore business models implemented, as well as their geographies of intervention (African, Asian and Latin American countries) (Eisenhardt \& Graebner, 2007). We also acknowledge the fact that we did not studied all the projects that $\mathrm{BoP}$ initiatives are implementing at the field level. However, their selection in agreement with corporate managers or directors was meant to be representative of their activities in BoP strategies. Moreover, the descriptive statistics analysis of quantitative data serves as a "subcase" analysis related to the broader cross-case analysis, as it is suggested for embedded, multiple-case studies (Yin, 2009, pp. 132-133; 2012, pp. 6-10). Finally, we analyzed secondary data to complete the triangulation of data acquired through interviews and survey questionnaires.

The first literature review on the BoP concept published by Kolk et al. (2012) emphasizes on the low number of empirical research work with only a small amount of the literature focusing on MNEs. Therefore the paper generally contributes to the BoP literature as it provides empirical elements to the discussion on its strategy, especially focusing on MNEs as the central entity addressed by Prahalad's initial work (Prahalad \& Fruehauf, 2004; Prahalad $\&$ Hart, 2002).

Our study also contributes to the literature that considers BoP initiative as an integrated part of Corporate Social Responsibility aimed at creating value for both the society and the company (Halme \& Laurila, 2009; Micheal Porter \& Kramer, 2011). BoP strategies as a component of the broader strategy of the firms has been poorly addressed in the literature. We reveal that the more CSR engagements are integrated into the firms' strategy, the more BoP strategies will maintain and scale up. We deliver novel insights for the study of the "business cases" of BoP strategies, which aim at gaining legitimacy, incubating strategic change and reaching profitable growth. In addition, our study reassert that deepened societal accountability of BoP initiatives tend companies to adopt non-traditional ways tracking social value creation. While, this is in opposition to Simanis and Milstein (2012) recommendation to rather focus on business metrics, such accountability appears to be determinant for initiatives relying on external funding or for mitigating reputational risks of "social washing".

We strongly encourage future research to explore the management control for sustainability performance, which will address the ways that companies' management are assessing the business case of BoP initiatives. Future studies could investigate the way companies integrate performance monitoring and impact measurement of social outcomes, beyond solely relying on a "simple" tracking of direct results.

\section{Acknowledgment:}

We are particularly grateful for the time spent and valuable insights brought by corporate managers and directors of BoP initiatives whom we interviewed as well as by projects managers at the field level who answered to the survey questionnaire. We wish to thank Patricia Crifo, Jean-Pierre Ponssard, Nicolas Mottis, and François Perrot from Ecole Polytechnique for their helpful support. We also thank the anonymous reviewers of the Environmental and Sustainability Management Accounting Network (EMAN) 2014 conferences, and the participants at the sessions where this paper was presented. The author gratefully acknowledges the financial support from the Business Sustainability Initiative and the chair for Sustainable Finance and Responsible Investment (FDIR) at the Europlace Institute of Finance, and from the ANR/Investissements d'avenir (ANR -11- IDEX0003-02).

\section{Appendix: Companies' case summary}

Danone is a French-based global leader in the food and beverage industry with market positioning in dairy products, bottled water, baby food and medical food. It permitted Danone to reach a turnover of $€ 20$ billion in 2012, employing 102000 people. In the past 10 years, the direction of Danone ambitioned to expand its traditional positioning in premium markets towards lower segments of the economic pyramid to find new growth opportunities. This major shift operated in 2003, when the company changed its slogan from "bringing health through food" to "bringing health through food to as many people as possible" (Faivre-Tavignot et al., 2010). It was translated into strategic plans with the company programme "New Danone" set in 2008 for which the executive board set four new priorities called "Health, For all, Nature and People". The "For all" priority, which focuses on opening the company to new lowerincome population market segments has been translated into two new entities: the danone.communities (d.c) fund and the "Base of the Pyramid" business unit (BoP BU), respectively created in 2008 and 2010 (Faivre-Tavignot, 2012). Until 2012, both entities hierarchically affiliated to the Middle East and Africa Business Unit, which focuses on emerging markets. At the time of writing 
this paper, Danone was redefining the "For All" priority and thus the $\mathrm{BoP}$ and social business approaches at the corporate level of the Group.

danone.communities is a dedicated mutual fund that invests in and supports the development of social businesses in the sense of Yunus (danone.communities, 2013; Yunus, 2008). Its governance is based on an independent Board of Directors, which decides for its strategic orientations, while its investment decisions follow a three-step approval through different committees. All of those entities are composed of Danone senior managers, experts in socially responsible investments and development in emerging economies, and bankers. In late 2013, d.c invested in 10 ventures, namely Grameen Danone Foods Ltd and JITA in Bangladesh, 1001 Fontaines in Cambodia, NutriGO in China, Isomir and Projet Malin in France, Naandi Community Water Services in India, El Alberto in Mexico, and La Laiterie du Berger and Lemateki in Senegal. Since 2012, d.c's corporate team is temporarily affiliated to the Deputy General Manager of the Group in charge of corporate functions but remains under the independent governance of its Board of Directors.

The BoP Business Unit, was in charge of transferring knowledge acquired within d.c to specifically target BoP market segments in a mass phenomena first across India. The BoP BU was in charge of creating the Fundooz' enriched yogurts brand in India. However, it was dismantled in 2012 due to the lack of time to create the product and its packaging, as well as to deliver sales figures. Moreover, investments in promotion and advertisement were too costly and degraded the P\&L. Danone's objectives to reach as many people as possible remains a strong objective, managed under a methodology called "Route to Market" (Danone, 2012, pp. 27-35). The deployment of products and brands towards BoP market segments is now decentralized to local country operations where the Group has enough brand recognition to expand its market penetration towards lower socioeconomic segments. Countries and subsidiaries use a "business model centric" approach to distribute adequately products and brands in emerging countries (Danone, 2013, pp. 22-27).

Electricité De France (EDF), is a French-based electricity utility leader in Europe with activities in generation, transmission, distribution, energy supply and trading. The Group generated consolidated sales of $€ 72.7$ billion in 2012 , of which $46.2 \%$ outside of France and employs 160000 people. Since the early 1990s, the EDF Group has been involved in promoting energy access in developing countries. First initiatives used a philanthropic approach to deliver decentralized electrification solutions in rural areas of Africa (Heuraux, 2010a).

In 1999, the company decides to take or support sustainable initiatives "to promote access to energy for communities". This commitment took the form in the "Agreements on EDF Group Corporate Social Responsibility" that were signed between all the stakeholders of the company (EDF, 2009). Its article 16 , called "Actions in favour of access to energy", clearly stipulates, "The signatories consider that access to energy is a major factor in social and economic development and a key factor in the fight against poverty". This shift in the company's societal engagement translated into the creation of dedicated business ventures, namely Decentralized Services Companies (DSCs) based on the model of Renewable Energy Service Company (RESCOs) (Heuraux, 2010b). DSCs are governed by local law, employing local managers and personnel. Every DSCs sell decentralized energy services for at least 10000 rural customers over a defined area, which they are granted under a concession for a renewable period of 15 to 25 years. Since the launch of the model, the Group's direction contributed to the funding of six SSDs through equity or debt in Botswana, Mali, Morocco, Senegal and South Africa (EDF, 2013). The Group's financial contribution represents an amount close to $€ 8$ million, alongside with funding from local companies or utilities, multinationals, banks, and development banks or agencies.

Access to energy projects within the Group are now managed from the "Africa and Access to Energy" department of the "International Development Division", which is affiliated to the Presidency of the Group. In respect with its strategy of transferring RESCOs to local partners, EDF sold its stakes of three of them, while it still contributes to their economic viability through continued skill support. Recently, the Mission objectives have been positively revalued by the management team to propose a systemic approach to the Group's partners. The Access to Energy Mission is also responsible to support access to energy solutions to local communities in the context of contracts of big infrastructures such as the Nam Theun 2 hydraulic power plant in Laos or peri-urban electrification schemes in Brazil, Argentina, South Africa and Morocco. This provides the Mission a transversal positioning within the Group. In parallel, the EDF Foundation contributes through project support with a specific focus with its newly renamed entity, EDF Help, which contributes through material, competency and financial support in case of emergency and relief situations or development projects. 
Essilor is a French-based leading ophthalmic optics company, which designs, manufactures and market lenses to improve and protect eyesight, as well as develops and markets equipment, instruments and services for eyecare professionals. Essilor reported consolidated revenue of approximately $€ 5$ billion in 2012 and employs 50700 people worldwide. The same year, Essilor celebrated the $40^{\text {th }}$ anniversary of the merger of the cooperative Essel and the company Silor that founded the Essilor Group. This merger stated the mission of the Group as "seeing the world better".

When the Group built its Sustainable Development direction in 2002, the company took stock on the fact that five billion people do not have access to vision professionals, while, among them, 2.5 billion do not have access to visual correction. Its new responsible mission has been "to enable as many people as possible to see the world better" (Essilor, 2007). Alongside the globalization strategy initiated by Xavier Fontanet, the former CEO, the sustainable development direction supported the Vice President South Asia, Middle-East, South Africa \& East Africa to create in 2006 an innovative business approach to reach profitably unprivileged people in rural India (Garrette, Benkirane, \& RogerMarchant, 2008). Essilor took advantage of a partnership with two large non-profit eye-care hospitals in India, namely Aravind and Sankara Nethralaya to develop mobile vans that perform insitu optometrist tests, lenses production and eyeglasses sales. Up to 12 vans developed by Essilor have been accompanying another series of 12 ophthalmologic vans owned by the two hospitals to perform distant consultations through satellite communication. This model permitted Essilor to follow the sustainable development direction rules to provide visual corrections following professionals' prescriptions and to remain in the formal economy. Although the 12 optometric mobile vans succeeded in reaching economic viability, the project has not been replicated on a larger scale due to two limiting factors. First, production capacity of lenses within the vans could not exceed 32 customers a day, lengthening the return on investment period. It was also far too few compared to the 5000 daily consultations the ophthalmologic vans could perform. Secondly, Essilor would have faced the low appeal from optometrists to travel in rural areas.

Since the arrival of Hubert Sagnières as the new CEO of Essilor in late 2011, Sustainable Development's image has been revalorized as a sales growth opportunity. For this purpose, $\mathrm{Mr}$ Sagnières created the "Corporate Mission" department, hierarchically and functionally related to the Direction and under the supervision of the former president of Essilor India. The Corporate Mission will be in charge of creating a "New Vision Generation" division, intended to be autonomous and independent from business, while targeting the 2.5 billion people that do not have access to visual corrections. Activities will start in Brazil, China, India, and Indonesia. A business-model centric approach will focus on creating a network of village level entrepreneurs who will perform visual detection in their villages. In parallel, standard lenses will be manufactured prior their shipment to customers. Product innovation also concerns the eyeglasses frames as lenses can be assembled on both sides. Such a model permits Essilor to control and reduce drastically the market retail price of eyeglasses while offering a large choice to customers. Essilor intends to reach 46 million people by 2020 , targeting a $10 \%$ of market share in countries it operates. Alongside the New Vision Generation division, the Corporate Mission department remains in charge of the Sustainable Development direction for reporting and communicating CSR integration and promoting internal ethics and business conduct principles, as well as the company's Foundation for charity activities. A last axis, the Vision Impact Institute, was created to advocate on the broad impact of vision correction.

Grundfos Holding A/S is a Danish-based leading pump manufacturer. Grundfos turnover in 2012 exceeded $€ 3$ billion and employs 18000 people working in more than 50 countries. Taking stock on the global concern about water management for a sustainable development, Grundfos reported the integration of environmental issues into its core activities since the early 2000's (Grundfos, 2002). In parallel, the Group initiated philanthropic activities towards society, in line with its first shareholder, The Poul Due Jensen Foundation, for which one of its mission is to donate to a number of charities and educational or scientifically oriented projects (Grundfos, 2008).

In 2009, Grundfos testifies for the integration of Corporate Social Responsibility as an essential element in its business strategies (Grundfos, 2009). The Group will commit with a "framework of shared value" both for the company and the society, two years before this concept will be popularized by Porter and Kramer (2011). In particular, the New Business division of the Business Development executive department of the Group will build Grundfos Lifelink. This new subsidiary venture aims at targeting rural communities in Africa, Asia and Latin America with a sustainable supply of safe drinking water at an affordable price. The company will innovate to offer a turnkey water solution 
integrating a standard Grundfos pump, renewable energy production, a water dispenser and mobile payment facilities. Since the launch of Grundfos lifelink in March 2009 in Kenya, this satellite company has covered 40 projects giving access to clean water to 100000 people, commissioned in partnership with local governments or development organizations (Grundfos, 2013a).

The pilot phase in Kenya demonstrated to the company's direction that a business case could exist in targeting the $\$ 8.4$ billion latent market for the water and sanitation sector composed of potential customers such as water utilities and players of the development sector. At the time of writing this paper, Grundfos Lifelink was being integrated back into the company, becoming a standalone division of the Business Development executive department. Lifelink was progressively getting the mandate to become responsible for this new market segment composed by the Base of the Pyramid endcustomers.

Lafarge is a French-based worldwide leader in building materials with activities in cement, aggregates and concrete. In 2012, Lafarge posted sales of $€ 15.8$ billion, and employs 68000 people. The company's responsibility started to formalize in the late 1990's with the parallel rise of concerns towards stakes of the extractive industry, and more specifically the cement industry. To tackle related issues, Lafarge built a stakeholder management approach; initiated numerous partnerships with NGOs such as WWF or CARE; and involved in the World Business Council for Sustainable Development's initiative on sustainable cement industry (Lafarge, 2003). Similarly, the company initiated charity partnerships with NGOs to address social issues such as housing projects for underprivileged people, which also focused on families living close to its production sites. In the mid 2000's, Lafarge took part in governmental social housing projects as a Public Relation lever. As highlighted by Perrot, "the BOP issue was mostly perceived as a social issue" and "Not a business opportunity" (2011, pp. 86-87).

First concern within Lafarge regarding the potential market that exists at the Base of the Pyramid segment emerged in 2007, through a research partnership with Ecole Polytechnique, France, initiated by the Strategy Direction of the company. Its newly "Sustainable Housing" programme performed market studies in Indonesia, which was under reconstruction phase after the tsunami that struck the country in 2004, and led to two pilot projects (Perrot, 2011, pp. 89-95). The first one, led by Lafarge Indonesia, consisted in a social housing project in Medan, Sumatra Island, in partnership with a professional association of real estate developers, the Indonesian government and the local municipality. The agreement secured the supply of cement to construct 5000 houses. The second project, focused on house or shop extensions needs rather than construction, which was unmet due to loan scarcity for low-income people. In partnership with the NGO Care, its Indonesian subsidiary specialized in microcredit, and local microfinance institutions, an innovative business models was created to combine microcredit, supply of cement, sensitization of borrowers, and skills support to local retailers and masons.

Learning from the pilot phase led the direction of Lafarge reconsider the BoP segment as "A business opportunity". An "Affordable Housing" division was created in 2012 under the newly Innovation Direction with double commercial and social impact objectives. While an internal innovation plan runs until 2015 with profit targets, the direction set a societal plan running until 2020. Among its nine ambitions, the Affordable Housing programme will have to "enable 2 million people to have access to affordable and sustainable housing" (Lafarge, 2012) . In late 2013, the Affordable Housing initiative was active in 15 countries, combining different market approaches: microcredit for individual home improvement or extension; "mass affordable" housing programmes with real-estate developers; rehabilitation of slums in-situ; and new generation social housing in developed countries.

Schneider Electric is a French-based leader in energy management with activities in utilities and infrastructure, industries and machines manufacturers, non-residential building, data centers and networks and in residential. In 2012, the company achieved revenues of $€ 24$ billion and employs 140000 people worldwide. Schneider Electric focuses on "making energy safe, reliable, efficient, productive and green", which highlights the environmental embeddedness into its core value proposition. The company's concern about societal responsibility first emerged in 1998 with the creation of the Schneider Electric Foundation (Vermot Desroches \& André, 2012). Its ethical mission based on philanthropy consists in promoting youth integration through vocational training in energy trades. Four years later, the Sustainable Development direction, affiliated to the Executive Strategy and Innovation direction, will be created to manage the strategic plans in terms of sustainability that are quarterly tracked under the Planet \& Society Barometer dashboard.

In 2009, following the goal of Jean-Pascal Tricoire, President and CEO, to improve the societal engagement and to reaffirm the innovation capacity 
of the firm, the Sustainable Development Direction launched the BipBop programme (Vermot Desroches \& André, 2012). BipBop stands for "Business, Innovation, and People at the Base of the Pyramid". The aim of the programme is to contribute to access to clean energy for low-income populations mainly in rural areas of Sub-Saharan Africa, India, and South-East Asia, through the development of a combined approach of philanthropy and business. The different pillars of the program aim at developing a local economic fabric through impact investments; deploying dedicated access to energy products and solutions through the creation of adapted business models; and promoting long-term competencies by sponsoring the creation of training with non-profit partners.

Since its launch, the BipBop programme, considered as an internal "start-up", knew a constant growth and integration within the company's organisation though the support from Research and Development, manufacturing plants, internal supply chain and local operations. Its objectives, both commercial and societal, increased every year. In late 2013, the programme had invested in eleven SMEs in the field of access to energy and job integration. The planet \& Society Barometer of the company testifies for having provided access to energy on a sustainable basis to close to two million people; and for having supported the creation of 40 training projects, which trained over 40000 people (Schneider Electric, 2011, 2013). At the time of writing this paper, the direction of the company was studying the potential to consider BipBop as a line of business regarding its commercial activity.

Veolia Environnement (Veolia) is a Frenchbased world leader in environmental solutions with activities in water management, waste management, and energy management for municipal and industrial clients. Veolia Environnement recoded revenue of $€ 29.4$ billion in 2012, and employs 220000 people. The company's position in the domain of public service delegation implies to target every socio-economic segment of populations where the company operates, either it is required by public policies or as a competitive advantage component of tenders. In the past 15 years, Veolia developed technical and industrial competencies in targeting low-income people through public-private partnerships.

The company recently reasserted its engagement to "contribute to local economic and social development and to meeting international goals for access to essential services" within its $11^{\text {th }}$ commitment of its Sustainable Development Charter (Veolia Environnement, 2013). In order to support decentralized business operations for societal engineering aspects, the Sustainable Development Direction created a methodology called "ACCES". The Direction capitalized on competencies acquired in specific tenders, which included social clause targeting low-income people. Acces provides technical support in optimizing exiting infrastructures and standpipes; financial and economical support in defining socially acceptable pricing policies and individuals socially assisted connections; as well as services and administrative support for social management department, community management or mobile sales office aspects. This led to the implementation of numerous projects, mainly in the water sector. In Morocco, a service contract delegation with the cities of Rabat, Tangier and Tetouan permitted to supply water and sanitation systems to 80000 families (Devoto, Duflo, Dupas, Pariente, \& Pons, 2011). The model relied on a combination of new standpipes, progressive pricing policy, individual socially assisted connections and mobiles sales office. In Bangladesh, Grameen Veolia Water Ltd, a Social Business Joint Venture created in 2008, built a small-scale water treatment plant to serve five villages and distribute bottled water in the capital city (Yunus, Sibieude, \& Lesueur, 2012).

At the time of writing this paper, Veolia initiated a recentralization of its different business segments and thus organization. Regarding access to essential services, the company was taking stock on the experiences in targeting low-income people to create a new division called "INNOVE" under the Market Innovation Direction. This new entity would now be responsible to initiate pilot projects and incubate business models on its own, with the support of local business operations of every segment. Then, successful projects would be transferred to traditional business operations, supplementing their strategic differentiation and offering new economic value added to their customers. 


\section{References}

Adler, P. A., \& Adler, P. (1987). Membership roles in field research. Newbury Park, CA: Sage Publications, 4(1), 7-24.

Ansari, S., Munir, K., \& Gregg, T. (2012). Impact at the 'Bottom of the Pyramid': The Role of Social Capital in Capability Development and Community Empowerment. Journal of Management Studies, 49(4), 813-842.

Arjaliès, D.-L., \& Ponssard, J.-P. (2010). A Managerial Perspective on the Porter Hypothesis. The Case of $\mathrm{CO}^{2}$ Emissions. In P. Crifo \& J.-P. Ponssard (Eds.), Corporate Social Responsibility: From Compliance to opportunity? (pp. 151-168): Les Editions de l'Ecole Polytechnique.

Arora, S., \& Romijn, H. (2012). The empty rhetoric of poverty reduction at the base of the pyramid. Organization, 19(4), 481-505.

Baddache, F. (2008). Procter \& Gamble: Providing Safe Drinking Water to the Poor GIM Case Study (Vol. A036, pp. 18). New York, USA: United Nations Development Programme

Bansal, P., \& Roth, K. (2000). Why companies go green: a model of ecological responsiveness. Academy of Management Journal, 43(4), 717-736.

Brannick, T., \& Coghlan, D. (2007). In Defense of Being "Native": The Case for Insider Academic Research. Organizational Research Methods, 10(1), 59-74.

Brugmann, J., \& Prahalad, C. K. (2007). Cocreating business's new social compact. Harvard Business Review, 85(2), 80.

Carroll, A. B. (1991). The pyramid of corporate social responsibility: Toward the moral management of organizational stakeholders. Business Horizons, 34(4), 3948.

Cholez, C., Trompette, P., \& Vinck, D. (2010). L'exploration des marchés BoP. Revue française de gestion(9), 117-135.

Clay, J. W. (2005). Exploring the links between international business and poverty reduction: A case study of Unilever in Indonesia: Oxfam.

Commission of the European Communities. (2001). Promoting a European framework for Corporate Social Responsibility Green Paper (pp. 32). Brussels.

Crabtree, A. (2007). Evaluating "The Bottom of the Pyramid" from a Fundamental Capabilities Perspective. Working Paper. Copenhagen Business School Centre for Business and Development Studies.

Danone. (2012). Danone 2011. Sustainability Report. Strategy and Performance (pp. 230).

Danone. (2013). Danone 2012. Sustainability Report. Strategy and Performance (pp. 176).

danone.communities. (2013). danone.communities Retrieved 10 September, 2013, from http://www.danonecommunities.com/en/home

Davidson, K. (2009). Ethical concerns at the bottom of the pyramid: where CSR meets BOP. Journal of International Business Ethics, 2(1).

Devoto, F., Duflo, E., Dupas, P., Pariente, W., \& Pons, V. (2011). Happiness on Tap: Piped Water Adoption in Urban Morocco. In N. B. o. E. Research (Ed.), (pp. 42).

EDF. (2009). Agreement on EDF Group Corporate Social Responsibility (pp. 25).

EDF. (2013). Energy Access - Developing Countries. Projects in Africa Retrieved 15 September, 2013, from http://aboutus.edf.com/strategy-and-sustainable-development/ourpriorities/society/energy-access-developingcountries/projects-in-africa-84686.html

Eisenhardt , K., \& Graebner, M. (2007). Theory Building From Cases: Opportunities and Challenges. Academy of Management Journal, 50(1), 25-32.
Eisenhardt, K. M. (1989). Building theories from case study research. Academy of management review, 14(4), 532-550.

Essilor. (2006). 2005 Annual Report. Different cultures, the same mission (pp. 60).

Essilor. (2007). Seeing the World Better / 2006 (pp. 60).

Faivre-Tavignot, B. (2012). Quels sont les processus qui permettent aux modèles sociétaux d'accès aux biens et services (social business et BoP) de constituer des leviers de renouveau stratégique de l'entreprise ? Le cas d'une multinationale de l'agroalimentaire. Doctorat, Lyon.

Faivre-Tavignot, B., Lehman-Ortega, L., \& Moingeon, B. (2010). Le social business, laboratoire d'apprentissage des stratégies de rupture. Revue française de gestion(9), 175189.

Garrette, B., Benkirane, K., \& Roger-Marchant, C. (2008). Essilor's "Base Of the Pyramid" Strategy in India. Paris, France.

Grundfos. (2002). Group Environmental Report 2001 (pp. 40).

Grundfos. (2008). Sustainability Report 2007 (pp. 60).

Grundfos. (2009). Sustainability Report 2008 (pp. 60).

Grundfos. (2013a). The CEO Water Mandate (pp. 28).

Grundfos. (2013b). The Grundfos Purpose Retrieved 16 May, 2013, from http://www.grundfos.com/about-us/introductionto-grundfos/the-grundfos-purpose.html

Hahn, R. (2009). The Ethical Rational of Business for the Poor Integrating the Concepts Bottom of the Pyramid, Sustainable Development, and Corporate Citizenship. Journal of Business Ethics, 84(3), 313-324.

Hahn, R. (2012). Inclusive business, human rights and the dignity of the poor: a glance beyond economic impacts of adapted business models. Business Ethics: A European Review, 21(1), 47-63.

Halme, M., \& Laurila, J. (2009). Philanthropy, Integration or Innovation? Exploring the Financial and Societal Outcomes of Different Types of Corporate Responsibility. Journal of Business Ethics, 84(3), 325-339.

Hart, S. (2007). Capitalism at the Crossroads. Aligning Business, Earth, and Humanity (2nd ed.). New Jersey: Wharton School Publishing.

Hart, S. L., \& Milstein, M. B. (2003). Creating sustainable value. The Academy of Management Executive, 17(2), 5667.

Heuraux, C. (2010a). Access to Energy in Developping Countries: EDF's Experience with Rural Electrification Using an Innovative Business Model. In P. Crifo \& J.-P. Ponssard (Eds.), Corporate Social Responsibility: From Compliance to Opportunity? (pp. 19). Palaiseau: Ecole Polytechnique.

Heuraux, C. (2010b). Histoire d'un concept innovant pour l'électrification rurale : les sociétés de services décentralisés. In Karthala (Ed.), L'Electricité au Coeur des Défis Africains. Manuel sur l'électrification en Afrique (pp. 36). Paris.

Hillemann, J., \& Verbeke, A. (2014). An internalization theory perspective on the Bottom of the Pyramid. Progress In International Business Research, 8, 69-90.

Karamchandani, A., Kubzansky, M., \& Lalwani, N. (2011). Is the bottom of the pyramid really for you? Harvard Business Review, 89(3), 107-111.

Karnani, A. (2006). Misfortune at the Bottom of the Pyramid. Greener Management International(51), 99-110.

Karnani, A. (2007a). Doing well by doing good-Case study: ‘Fair \& Lovely'whitening cream. Strategic management journal, 28(13), 1351-1357.

Karnani, A. (2007b). Fortune at the Bottom of the Pyramid: A Mirage. Ross School of Business Paper, 1035, 42. 
Keating, C., \& Schmidt, T. (2008). Opportunities and challenges for multinational corporations at the base of the pyramid. In P. Kandachar \& M. Halme (Eds.), Sustainability Challenges and Solutions at the Base of the Pyramid: Business, Technology and the Poor (pp. 387-410). Sheffield, UK: Greenleaf Publishing Limited.

Kennedy, R., \& Novogratz, J. (2011). Innovation for the BoP: the patient capital approach. In T. London \& S. L. Hart (Eds.), Next Generation Business Strategies for the Base of the Pyramid (pp. 45-76). Upper Saddle River, NJ.

Kolk, A., Rivera-Santos, M., \& Rufin, C. (2012). Reviewing a Decade of Research on the 'Base/Bottom of the Pyramid' (BOP) Concept. Business \& Society, 36.

Kurucz, E. C., Colbert, B. A., \& Wheeler, D. (2008). The Business Case for Corporate Social Responsibility. In A. Crane, A. McWilliams, D. Matten, J. Moon \& D. Seigel (Eds.), The Oxford Handbook on Corporate Social Responsibility (pp. 83-112). Oxford: Oxford University Press.

Lafarge. (2003). Our Second Sustainability Report (pp. 4).

Lafarge. (2012). Sustainability. Our Ambitions for 2020 (pp. $24)$.

London, T. (2008). The Base of the Pyramid Impact Assessment Framework: Understanding and Enhancing Value Creation. William Davidson Institute.

London, T. (2010, August). Business Model Development for the Base-of-the-Pyramid Market Entry. Paper presented at the Academy of Management Annual Meeting.

London, T., \& Hart, S. L. (2004). Reinventing Strategies for Emerging Markets: Beyond the Transnational Model. Journal of International Business Studies, 35(5), 350-370.

Mary, S. (2013). Inclusive Business ESG Sustainability Research (pp. 68): Crédit Agricole Chevreux.

Matambanadzo, P. (2001). HP's World eInclusion: Strategy Document for implementation of eJobs in Developing Countries (pp. 29).

McFalls, R. (2007). Testing the Limits of Inclusive Capitalism. Journal of Corporate Citizenship, 2007(28), 85-98.

Munir, K., Ansari, S., \& Gregg, T. (2010). Beyond the hype: Taking business strategy to the "bottom of the pyramid". Advances in Strategic Management, 27, 247-276.

Murphy, M., Perrot, F., \& Rivera-Santos, M. (2012). New perspectives on learning and innovation in cross-sector collaborations. Journal of Business Research, 10.

Natixis. (2012). ISR / Bottom of the pyramid Etudes ISR Recherche Action (pp. 95): Natixis Equity Markets.

P\&G. (2011). P\&G Underlines Commitment to Its Children's Safe Drinking Water Program.

Perrot, F. (2010). Corporate Strategies and the Construction of Markets at the Base of the Pyramid. In P. Crifo \& J.-P. Ponssard (Eds.), Corporate Social Responsibility: From Compliance to opportunity? (pp. 233-253): Les Editions de l'Ecole Polytechnique.

Perrot, F. (2011). Multinational Corporations at the base of the Economic Pyramid: A Strategic Analysis Framework. Ecole Polytechnique, Palaiseau.

Porter, M. (2000). Location, Competition, and Economic Development: Local Clusters in a Global Economy. Economic Development Quarterly, 14(1), 15-34.

Porter, M., \& Kramer, M. (2011). Creating Shared value. How to reinvent capitalism and unleash a wave of innovation and growth. Harvard Business Review, 17.

Prahalad, C. K., \& Fruehauf, H. (2004). The Fortune at the Bottom of the Pyramid: Eradicating Poverty Through Profit: Wharton School Publishing.

Prahalad, C. K., \& Hammond, A. L. (2002). Serving the World's Poor, Profitably. Harvard Business Review, 80(9), 10.
Prahalad, C. K., \& Hart, S. (1999). Strategies for the Bottom of the Pyramid: Creating Sustainable Development. Ann Arbor and Chapel Hill.

Prahalad, C. K., \& Hart, S. (2002). The Fortune at the Bottom of the Pyramid. Strategy+Business(26), 15.

Reficco, E., \& Márquez, P. (2012). Inclusive Networks for Building BOP Markets. Business \& Society, 51(3), 512-556.

Rivera-Santos, M., \& Rufín, C. (2010). Global village vs. small town: Understanding networks at the Base of the Pyramid. International Business Review, 19(2), 126-139.

Schneider Electric. (2011). The Planet \& Society Barometer Letter. Annual results 2011. 6.

Schneider Electric. (2013). Schneider Electric Extra-financial results Q3 2013 (pp. 16).

Schwittay, A. (2011). The Marketization of Poverty: with CA comment by Krista Badiane and David Berdish. Current Anthropology, 52(S3), S71-S82.

Seelos, C., \& Mair, J. (2007). Profitable Business Models and Market Creation in the Context of Deep Poverty: A Strategic View. The academy of management perspectives, 21(4), 49-63.

Sen, A. (1992). Inequality, reexamined: Oxford University Presse.

Simanis, E. (2012). Reality Check at the Bottom of the Pyramid. Harvard Business Review, 90(6), 6.

Simanis, E., \& Hart, S. (2008). The Base of the Pyramid Protocol: Toward Next Generation BoP Strategy Second Edition (pp. 57). Ithaca: Cornell University.

Simanis, E., \& Milstein, M. (2012). Back to Business Fundamentals: Making BoP Relevant to Core Business. Field Actions Science Report(Special Issue 4), 8.

SNV, \& WBCSD. (2008). Inclusive Business: Profitable business for successful development (pp. 20): Alliance for Inclusive Business.

Thieme, T., \& DeKoszmovszky, J. (2012). Community Cleaning Services: combining market- and donor-based approaches to urban sanitation and youth engagement. Field Actions Science Report, Fighting Poverty, between market and gift(Special Issue 4), 8 .

Traça, D., \& Foryt, S. (2004). Bridging the Digital Divide (A). HP's e-Inclusion. [Case study 5168]. INSEAD, 25.

Veolia Environnement. (2013). 2012 CSR Performance Digest (pp. 120).

Vermot Desroches, G., \& André, T. (2012). The BipBop programme: Providing access to reliable, affordable and clean energy with a combined approach of investment, offers and training. Field Actions Science Reports [online], (Special Issue 6). Retrieved from http://factsreports.revues.org/1997

Walsh, J. P., Kress, J. C., \& Beyerchen, K. W. (2005). Book Review Essay: Promises and Perils at the Bottom of the Pyramid. Administrative Science Quarterly, 50(3), 473-482.

Warnholz, J.-L. (2007). Poverty Reduction for Profit? A Critical Examination of Business Opportunities at the Bottom of the Pyramid Working Paper: Queen Elizabeth House, University of Oxford.

Yin, R. (1994). Case study research: Design and methods (2nd ed.): SAGE Publications, Inc.

Yin, R. (2009). Case study research: Design and methods (4th ed.): SAGE Publications, Inc.

Yin, R. (2012). Applications of Case Study Research (3rd ed.): SAGE Publications, Inc.

Yunus, M. (2008). Creating a World Without Poverty: Social Business and the Future of Capitalism: PublicAffairs.

Yunus, M., Sibieude, T., \& Lesueur, E. (2012). Social Business and big business: innovative, promising solutions to overcome poverty? FACTS Reports(Special Issue 4). 